\begin{tabular}{|c|c|c|}
\hline 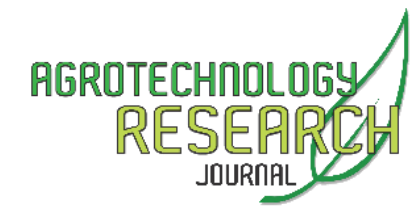 & $\begin{array}{c}\text { Agrotech Res J, December 2019, 3(2):115-120 } \\
\text { AGROTECHNOLOGY RESEARCH } \\
\text { JOURNAL }\end{array}$ & $\begin{array}{l}\text { ISSN 2655-7924 (Print) } \\
\text { ISSN 2614-7416 (Online) } \\
\text { https://jurnal.uns.ac.id/arj } \\
\text { doi: 10.20961/agrotechresj.v3i2.34761 }\end{array}$ \\
\hline
\end{tabular}

\title{
Kualitas Kimia Serat beberapa Klon Rami Asal Sumatera Barat
}

\author{
Denny Yulfa $^{1^{*}}$, Reni Mayerni ${ }^{2}$, Yusniwati Yusniwati ${ }^{3}$ \\ 1,2Department of Agronomy, Faculty of Agriculture, Universitas Andalas, Padang, Indonesia \\ ${ }^{3}$ Department of Agrotechnology, Faculty of Agriculture, Universitas Andalas, Padang, Indonesia
}

\section{${ }^{*}$ Corresponding Author:}

E-mail: dennyyulfa.20@gmail.com

Received 2 October 2019; Accepted 20 December 2019; Published 30 December 2019

\begin{abstract}
Flax/jute is natural fiber plants that that produce fiber from the bark. Ramie fiber has a better quality than the others natural fiber, so it can meet fiber the increase needs cultivar with the best chemical composition of fiber. The aim of this study was to detect the chemical composition of fiber in several clones of ramie from West Sumatera. The study was conducted on December 2018 at the Laboratory of Technology Agriculture Product Andalas University for analyzed the content of chemical composition (water, ash, holocellulose, cellulose, hemicellulose, and lignin). The result of this study showed that the highest level of water content, ash, hemicellulose, and lignin were found in Situjuah clones those are $40.43,6.74,14.39$, and $9.98 \%$ respectively. Whereas for the highest level of holocellulose and cellulose contents were in Ramindo 1 clone those were 70.23 and $58.46 \%$ respectively.
\end{abstract}

(C) 2019 Agrotechnology Research Journal

Keywords: Clone; Fiber; Ramie; Boehmeria nivea L.

Cite This As: Yulfa D, Mayerni R, Yusniwati Y. 2019. Kualitas Kimia Serat beberapa Klon Rami Asal Sumatera Barat. Agrotech Res J 3(2): 115-120. https://doi.org/10.20961/agrotechresj.v3i2.34761

\section{PENDAHULUAN}

Seiring dengan perkembangan industri tekstil di Indonesia yang semakin meningkat, maka kebutuhan bahan baku serat kapas juga terus meningkat. Namun, untuk memenuhi kebutuhan bahan baku tersebut Indonesia harus mengimpor serat kapas setiap tahun. Menurut Direktorat Jenderal Perkebunan (2017), pada tahun 2015 Indonesia mengimpor serat kapas sebesar 679.455 ton dengan nilai US $\$ 1,1$ juta sedangkan pada tahun 2016 terjadi penurunan bahwa Indonesia mengimpor serat kapas sebesar 485.744 ton dengan nilai US\$758.474.

Salah satu upaya untuk mengatasi ketergantungan bahan baku industri tekstil yang sangat tinggi terhadap kapas impor yaitu dengan menggunakan serat alam lain. Serat alam yang berpotensi untuk dijadikan bahan baku industri tekstil di Indonesia adalah rami (Boehmeria nivea (L.) Gaud). Hal ini dikarenakan tanaman rami memiliki sifat-sifat dan karakteristik seperti kapas dan memiliki bermutu tinggi.

Rami merupakan tanaman serat alam yang menghasilkan serat dari kulit batang. Serat rami memiliki kualitas yang lebih baik dibandingkan dengan serat alam lain seperti bambu, kenaf, flax, jute, kapas, dll. Selain

This is an open access article

Licensed under the Creative Commons Attribution International License CC-BY-SA 4.0

(cc) BY-SA serat rami yang dapat digunakan sebagai bahan baku dalam industri tekstil, pulp dan kertas, tanaman ini juga bisa digunakan sebagai konservasi lahan, pembuatan kompos, akar digunakan sebagai obat tradisional, dan daun digunakan sebagai bahan pakan ternak, serta berbagai macam produksi industri lain.

Produktivitas serat rami tergantung tinggi dan diameter batang, tebal-tipis kulit serta rendemen serat (kandungan serat per batang). Batang rami dipanen untuk produksi serat setiap 2 bulan sekali sehingga 1 tahun (di daerah tropis) dapat dilakukan 5-6 kali panen (Trisiana et al. 2016). Menurut Sarkar et al. (2010), serat yang dihasilkan dari rami sangat kuat dibandingkan dari semua tanaman yang berbasis serat bahkan lebih dari dua kali lipat dari serat kapas. Serat rami diekstraksi dari lapisan pohon induk memiliki beberapa kelebihan yaitu tekstur halus, panjang, dan kuat, hal ini sangat baik dan penting untuk serat alami.

Selain itu, serat rami juga memiliki keunggulan lain seperti resistensi terhadap bakteri dan kekuatan tarik yang lebih tinggi di bawah kondisi higroskopik (Satya et al. 2013). Menurut Liu et al. (2015) tinggi tanaman rami merupakan faktor penentu utama untuk hasil serat, karena serat rami diekstraksi dari kulit batang sehingga jika batang rami lebih pendek maka hasil serat juga lebih sedikit. Begitu pula hasil penelitian dari Zhu et al. (2012) mengungkapkan bahwa panjang dan diameter batang rami juga menentukan hasil serat. Bahkan hasil penelitian Liu et al. (2014) menyatakan 
bahwa hasil serat rami sangat ditentukan oleh beberapa komponen, termasuk jumlah batang per tanaman, hasil serat per batang, panjang batang, diameter batang, dan ketebalan kulit.

Sementara itu, di Indonesia sangat baik untuk budidaya rami karena menurut Mayerni (2006), tanaman mudah tumbuh di daerah tropis dan akan berproduksi tinggi di dataran rendah sampai tinggi $(10-1500 \mathrm{~m}$ di atas permukaan laut). Di Sumatera Barat, kawasan hutan masih sangat luas dengan berbagai macam vegetasi di sekitarnya, rami masih banyak ditemukan secara liar dan jenis belum diketahui. Selain itu, untuk memenuhi kebutuhan serat rami di Indonesia yang semakin meningkat, sehingga dapat memenuhi kebutuhan serat diperlukan kultivar dengan komposisi kimia serat terbaik.

Berdasarkan komposisi kimia serat, serat rami juga termasuk serat alam yang mengandung lignoselulosa yang selain dapat digunakan sebagai sumber serat untuk berbagai kebutuhan, dapat juga dimanfaatkan sebagai sumber selulosa bernilai ekonomi relatif tinggi karena pemanfaatan sangat luas. Komposisi kimia yang berhubungan dengan pemanfaatan serat alam ditentukan oleh kadar selulosa. Selulosa merupakan komponen struktural utama dinding sel tanaman hijau. Potensi ketersediaan serat selulosa yang besar dari tanaman dapat dikembangkan lebih lanjut untuk menghasilkan produk yang lebih bermanfaat dan bernilai tinggi (Putera 2012). Oleh karena itu, penelitian ini bertujuan untuk mendeteksi kadar komposisi kimia serat pada beberapa klon rami asal Sumatera Barat.

\section{BAHAN DAN METODE}

Penelitian ini dilakukan pada bulan Desember 2018 di Laboratorium Teknologi Hasil Pertanian Universitas Andalas. Pelaksanaan pengamatan komposisi kimia serat tanaman rami mengacu pada standar TAPPI (Technical Association for Pulp and Paper Industry) (2018) meliputi pengujian kadar air, kadar abu, kadar holoselulosa, kadar selulosa, dan kadar lignin. Penelitian ini dilakukan dengan menggunakan metode analisis deskriptif dan untuk penyajian data berdasarkan hasil pengamatan dari analisis komposisi kimia serat dengan cara angka yang telah didapatkan dari hasil analisis sebelumnya kemudian dihitung dengan menggunakan rumus.

\section{Pengujian kadar air}

Pengujian kadar air pada tahapan pertama, sampe ditimbang dengan berat 2 gram $\left(\mathrm{BKT}_{0}\right)$, kemudian sampel di oven pada suhu $105 \pm 3^{\circ} \mathrm{C}$ selama 3 jam. Setelah itu, dipindahkan ke dalam desikator selama 15 menit untuk didinginkan dan kemudian ditimbang hingga beratnya konstan (BKT $)$. Nilai kadar air dihitung berdasarkan rumus:

Kadar air $=\frac{B K T_{0}-B K T_{1}}{B K T_{0}} \times 100 \%$

Keterangan:

$\mathrm{BKT}_{0}=$ Berat kering serbuk awal (gram)

$B K T_{1}=$ Berat kering serbuk setelah ekstraksi (gram)

\section{Pengujian kadar abu}

Pengujian kadar abu dilakukan dengan menimbang sampel dengan kadar airnya 2 gram lalu dipanaskan selama 3 jam. Selanjutnya sampel dimasukkan ke dalam tanur dengan suhu $900^{\circ} \mathrm{C}$ dan dibiarkan suhu tersebut turun hingga $150^{\circ} \mathrm{C}$. Setelah itu sampel dikeluarkan dan dinginkan dalam desikator. Nilai kadar abu dihitung berdasarkan rumus:

Kadar abu $=\frac{A}{B} \times 100 \%$

Keterangan:

$A=$ Berat abu (gram)

$\mathrm{B}=$ Berat serbuk awal (gram)

\section{Pengujian kadar holoselulosa}

Sampel yang kering ditimbang sebanyak 2 gram dan dimasukkan ke dalam Erlenmeyer, setelah itu tambahkan Aquades $160 \mathrm{ml}$ untuk satu sampel, selanjutnya tambahkan 1,5 gram $\mathrm{NaClO}_{2}$ dan asam asetat $\left(\mathrm{CH}_{3} \mathrm{COOH}\right) 10$ tetes lalu diaduk dengan hati-hati. Pemanasan larutan selama 3 jam dengan suhu $75^{\circ} \mathrm{C}$, setiap 1 jam ditambahkan 1,5 gram $\mathrm{NaClO}_{2}$ dan asam asetat $\left(\mathrm{CH}_{3} \mathrm{COOH}\right) 10$ tetes. Setelah itu, sampel didinginkan pada suhu ruang, setelah itu sampel disaring dengan kertas saring lalu didinginkan dalam desikator dan kemudian sampel ditimbang. Kadar holoselulosa dihitung berdasarkan rumus berikut :

Kadar holoselulosa $=\frac{A}{B} \times 100 \%$

Keterangan:

$A=$ Berat holoselulosa (gram)

$\mathrm{B}=$ Berat serbuk awal (gram)

\section{Pengujian kadar selulosa}

Sampel ditimbang sebanyak 2 gram dan kemudian dipanaskan di dalam Erlenmeyer $200 \mathrm{ml}$ lalu ditambahkan $\mathrm{H}_{2} \mathrm{SO}_{4} \quad 1,3 \%$ selama 2 jam. Setelah itu, larutan tersebut disaring lewat fritted lalu dikeringkan di dalam oven pada suhu $105^{\circ} \mathrm{C}$, dan selanjutnya di dinginkan di dalam desikator dan kemudian ditimbang. Untuk mengetahui kadar selulosa digunakan rumus sebagai berikut :

Kadar selulosa $=\frac{A}{B} \times 100 \%$

Keterangan:

$A=$ Berat selulosa (gram)

$\mathrm{B}=$ Berat serbuk awal (gram)

\section{Pengujian kadar hemiselulosa}

Untuk mengetahui hasil pengujian dari kadar hemiselulosa didapatkan dengan cara pengurangan dari hasil analisis sebelumnya.

\section{Pengujian kadar lignin}

Pada pengujian kadar lignin, sampel ditimbang sebanyak 2 gram serat yang telah diekstraksi lalu masukkan ke dalam Erlenmeyer 500 ml. Kemudian dicampurkan $25 \mathrm{ml} \mathrm{H}_{2} \mathrm{SO}_{4}$ dibiarkan selama 2 jam pada suhu ruang, setelah 2 jam ditambahkan Aquades sebanyak $500 \mathrm{ml}$ dan dipanaskan hingga mendidih 
selama 4 jam. Setelah itu, larutan didinginkan semalaman dan besok harinya larutan disaring dengan kertas saring. Selanjutnya sampel di oven pada suhu $105^{\circ} \mathrm{C}$ selama satu hari, lalu sampel dikeringkan dalam desikator dan ditimbang. Untuk mengetahui kadar selulosa digunakan rumus sebagai berikut:

Kadar lignin $=\frac{A}{B} \times 100 \%$

Keterangan:

$A=$ Berat lignin (gram)

$\mathrm{B}=$ Berat serbuk awal (gram)

\section{HASIL DAN PEMBAHASAN \\ Kadar air}

Kadar air merupakan salah satu komponen sangat penting pada bahan serat alam, karena air dapat mempengaruhi penampakan dan tekstur serat rami. Kadar air juga menentukan bakteri maupun jamur untuk berkembang biak sehingga akan terjadi perubahan penampakan dan tekstur maupun kualitas serat rami. Menurut Mayerni (2006), persentase air tinggi dapat menyebabkan serat rami mudah lapuk. Hasil pengujian kadar air dapat dilihat pada Gambar 1.

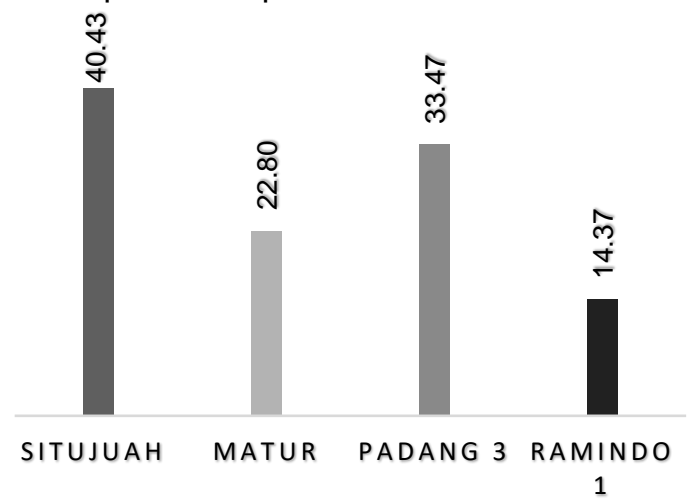

Gambar 1. Kadar air empat klon rami

Gambar 1, menandakan bahwa serat rami berkadar air paling tinggi adalah aksesi Situjuah sebesar 40,43\%, diikuti oleh klon Padang 3 sebesar 33,47\%, aksesi Matur sebesar 22,80\%, dan klon Ramindo 1 sebesar $14,37 \%$ (terendah di antara semua populasi tanaman rami). Kandungan air tinggi pada aksesi Situjuah ini karena dipengaruhi oleh lokasi tumbuh maupun sifat genetik dari tanaman. Sesuai dengan pernyataan Sunardi dan Istikowati (2012) juga Mayerni et al. (2018) bahwa perbedaan kadar air pada setiap tanaman dipengaruhi oleh lokasi tumbuh atau keadaan lingkungan sekitar, jenis klon, dan sifat genetik tanaman. Kadar air pada tumbuhan lebih tinggi di tempat basah atau lembap dibandingkan di tempat kering. Selain itu, kandungan air rendah dapat menyebabkan perkembangan akar terbatas, sehingga akan mengganggu proses penyerapan air dan unsur hara oleh akar tanaman. Menurut Subandi (2011), pada kondisi tanaman rami terlalu tua terjadi transformasi selulosa dalam serat digunakan untuk pemasakan biji, sehingga kandungan air di dalam batang rami turun sehingga serat-serat di antara kulit batang saling mengikat lebih erat.

\section{Kadar abu}

Kadar abu merupakan residu anorganik atau mineral yang didapat dari hasil sisa pembakaran suatu bahan organik. Komponen dan kadar abu tergantung pada kriteria bahan dan cara untuk mengukur.

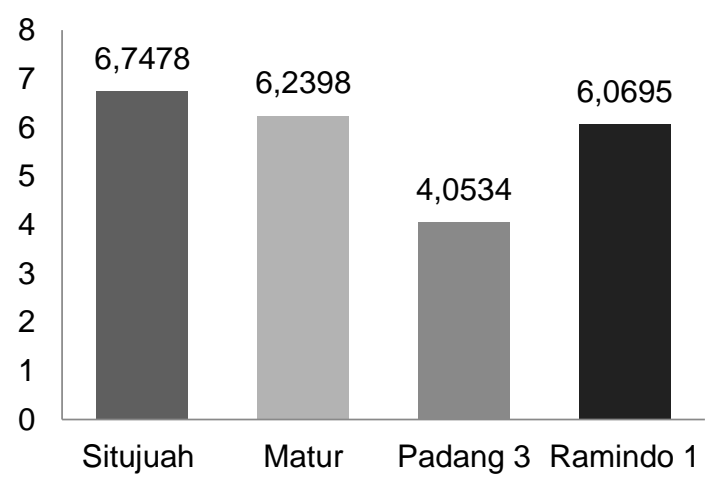

Gambar 2. Kadar abu dari empat populasi tanaman rami

Kadar abu pada aksesi situjuah paling tinggi, kemudian disusul oleh aksesi Matur, Ialu klon Ramindo 1 , dan yang paling rendah terdapat pada klon Padang 3 , masing-masing 6,74, 6,23, 6,06, dan 4,05\%. Hasil tersebut menunjukkan bahwa kadar abu dari aksesi Situjuah, Matur, dan klon Ramindo 1 sangat berbeda jauh dengan klon Padang 3 (Gambar 2). Hal ini juga dapat dipengaruhi oleh bobot serat kasar yang telah dilakukan sebelumnya, klon Padang 3 menghasilkan bobot serat kasar paling rendah di antara semua populasi rami.

Mayerni et al. (2018) menyatakan bahwa semakin tinggi kadar abu maka semakin tinggi pula kadar mineral pada serat dan kualitas serat akan menurun. Hal sama juga dinyatakan oleh Pasaribu (2007) bahwa kadar abu yang tinggi tidak diharapkan dalam pembuatan pulp dan kertas, hal ini terjadi karena abu tersebut dapat mempengaruhi kualitas kertas. Menurut Maulana (2016) bahwa kadar abu berkaitan dengan kandungan mineral suatu bahan serat alam yang secara tidak langsung akan memberikan efek terhadap sifat fisik serat tersebut.

\section{Kadar holoselulosa}

Kadar holoselulosa merupakan fraksi total karbohidrat dan untaian selulosa ditambah hemiselulosa kemudian direkatkan oleh lignin. Menurut Bahtiar et al. (2016) dinding sel tanaman berkayu menjadi lebih kuat. Kadar holoselulosa tertinggi pada klon Ramindo 1 sebesar $70,23 \%$ sedangkan yang terendah terdapat pada aksesi Situjuah dengan jumlah kadar $41,55 \%$, setelah itu aksesi Matur dan klon Padang 3, masing-masing 57,81\% dan 55,03\% (Gambar 3).

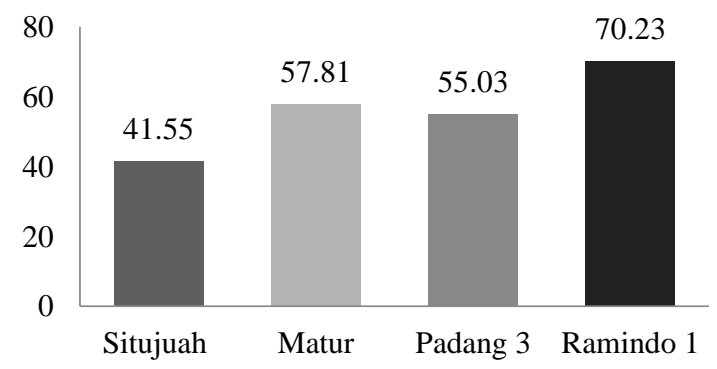

Gambar 3. Kadar holoselulosa dari empat populasi tanaman rami 
Menurut Putra et al. (2018) bahwa klasifikasi komponen kimia terkhusus kadar holoselulosa di atas $45 \%$ termasuk kriteria tinggi. Kadar holoselulosa yang tinggi akan menyebabkan kadar lignin menjadi rendah atau sebaliknya (Bahtiar et al. 2016; Lukmandaru et al. 2016), hal ini sesuai dengan analisis yang dilakukan terhadap kadar lignin, disajikan pada Gambar 6. Roza (2009) menyatakan bahwa kadar holoselulosa sangat menentukan kekerasan papan serat yang dihasilkan. Menurut Sunardi dan Istikowati (2012), kadar holoselulosa yang tinggi sangat baik digunakan untuk pembuatan pulp dan kertas karena akan memberikan daya tarik tinggi sehingga ikatan antar serat akan kuat dan tidak mudah lepas. Selain itu juga kekuatan lipat kertas akan tinggi dan tidak mudah sobek. Hasil penelitian ini tidak sejalan dengan hasil penelitian Putra et al. (2018), yang menyatakan bahwa kandungan holoselulosa tinggi diduga karena pengaruh perkembangan serat yang meningkat seiring peningkatan tinggi pohon hingga pada ketinggian tertentu.

\section{Kadar selulosa}

Selulosa merupakan komponen utama penyusun dinding sel tanaman. Selulosa lebih tahan terhadap reaksi kimia jika dibandingkan dengan hemiselulosa begitu pula sebaliknya (Novika 2013). Kadar selulosa tertinggi terdapat pada klon Ramindo 1 yang dikuti oleh aksesi Matur, Padang 3, dan Situjuah (Gambar 4). Masing-masing sebesar 58,46, 54,03, 45,11, dan $27,16 \%$. Kualitas serat akan meningkat seiring dengan peningkatan selulosa. Selain kualitas serat meningkat, Putera (2012) menyatakan bahwa ketersediaan selulosa yang tinggi akan lebih tahan terhadap bahan kimia, cahaya, mikroorganisme, tidak larut dalam air, tidak larut dalam pelarut organik, dan berwarna putih.

Menurut Putera (2012); Nurnasari dan Nurindah (2017), serat alam dengan selulosa tinggi mampu memperbaiki sifat mekanis pada bahan baku produk komposit berupa polimer. Selulosa dapat terbentuk karena struktur kristalin dan amorf serta beberapa mikro fibril yang akan membentuk fibril dan kemudian membentuk selulosa. Kualitas dan variasi sifat struktur serat dapat dipengaruhi oleh beberapa kondisi seperti tempat pertumbuhan, iklim, klon, dan usia tanaman. Kandungan selulosa tinggi pada serat rami juga akan meningkatkan kekuatan tarik dan modus elastis serat itu, sehingga kadar selulosa pada serat rami yang tinggi sangat baik dalam industri tekstil. Kadar selulosa dengan derajat kemurnian di atas $92 \%$ dapat digunakan sebagai bahan baku pembuatan propelan, sedangkan dengan derajat kemurnian di bawahnya dapat digunakan sebagai bahan baku industri pembuatan pulp dan kertas serta kain.

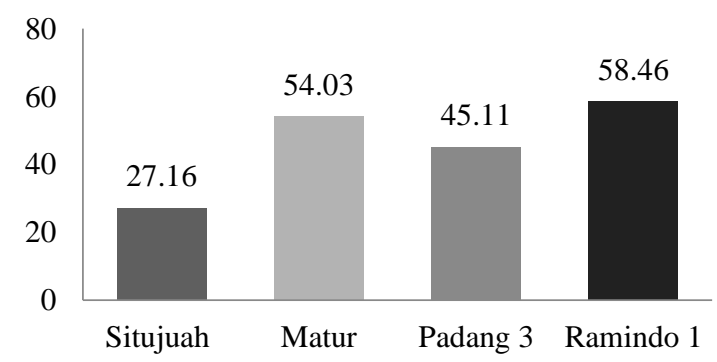

Gambar 4. Kadar selulosa dari empat populasi tanaman rami

\section{Kadar hemiselulosa}

Kadar hemiselulosa merupakan kelompok senyawa yang secara bersama-sama terikat dengan variabel selulosa pada bagian-bagian tanaman (Novika 2013). Hemiselulosa juga berfungsi sebagai perekat dan mempercepat pembentukan serat (Putera 2012), selain itu menurut Pasaribu (2007) bahwa hemiselulosa juga merupakan polimer amorf yang berasosiasi dengan selulosa dan lignin.

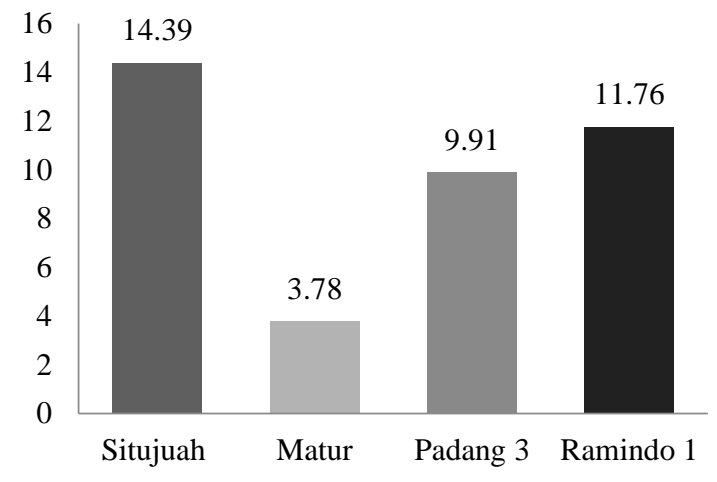

Gambar 5. Kadar hemiselulosa dari empat populasi tanaman rami

Kadar hemiselulosa tertinggi terdapat pada klon Situjuah sebesar $14,39 \%$, sedangkan terendah pada klon Matur sebesar 3,78\% (Gambar 5). Perbedaan tersebut bisa terjadi karena faktor lingkungan dan genetik tanaman juga bisa dari perbedaan bibit. Menurut Putera (2012) rantai pada hemiselulosa lebih pendek daripada pada selulosa, hal ini dikarenakan derajat polimerisasi yang lebih rendah. Polimer yang tidak lurus dan tidak terbentuk kristal menyebabkan kadar hemiselulosa lebih mudah dimasuki pelarut dan bereaksi dengan bahan kimia. Pasaribu (2007) menyatakan bahwa sifat hemiselulosa ini mudah mengalami depolimerisasi, hidrolisis oleh asam, basa, dan juga mudah larut dalam air, serta memiliki ikatan yang lebih kuat dengan lignin daripada dengan selulosa. Nurnasari dan Nurindah (2017) menambahkan bahwa kandungan hemiselulosa yang tinggi dapat mempengaruhi sifat fisik serat seperti lebih fleksibel, elastis, dan lebih mudah mengembang karena daya serap air lebih tinggi. juga dapat terjadi mudah mengalami perubahan tekstur. Sifat seperti ini juga sangat diperlukan untuk proses pembuatan pulp dan kertas, karena serat bersifat fisik demikian menyebabkan terbentuk luas permukaan yang tinggi sehingga dapat menghasilkan produk lebih baik. Selain itu ditambahkan oleh Pasaribu (2007) bahwa dalam pembuatan kertas terutama pada pembuatan bubur kayu, peran hemiselulosa sangat penting karena sifat dari gelatin memudahkan terbentuk sifat hidrofilik pulp sehingga memudahkan ikatan antar serat.

\section{Kadar lignin}

Kadar lignin merupakan bagian dari tanaman yang tidak dapat dicerna dan saling berikatan kuat dengan selulosa dan hemiselulosa (Novika 2013). Serat rami aksesi Situjuah mengandung lignin tertinggi dan dikuti Matur, Padang 3, dan Ramindo 1, kadar lignin masingmasing 9,98, 7,77, 6,83, dan 5,32\% (Gambar 6). Semakin tua tanaman semakin keras kulit tanaman, 
ditandai dengan peningkatan kadar lignin. Menurut Putera (2012) begitu pula Sunardi dan Istikowati (2012) menyatakan bahwa lignin berada di antara sel-sel dan di dalam dinding sel, berfungsi sebagai perekat di antara sel-sel tersebut secara bersama-sama. Di dalam dinding sel, lignin juga sangat berkaitan erat dengan kadar selulosa yang berfungsi memberikan ketegaran pada sel. Perubahan kandungan air di dalam tanaman lignin juga berpengaruh dalam memperkecil perubahan dimensi serat.

Menurut Nurnasari dan Nurindah (2017) bahwa kadar lignin yang tinggi dapat menyebabkan pengerasan pada dinding sel kulit tanaman sehingga menghambat enzim untuk mencerna serat dengan normal. Kandungan lignin tinggi akan menghasilkan produk yang tidak kuat. Lignin di dalam serat dapat mengurangi daya pengembangan dan ikatan antar serat. Jumlah kadar lignin dalam sebatang tanaman antara 10 hingga $50 \%$ dan jumlah ini tergantung spesies dan maturitas tanaman (Putera 2012).

Menurut Sunardi dan Istikowati (2012) semakin rendah kadar lignin akan semakin besar kadar selulosa. Jika kandungan lignin serat tinggi maka kualitas kurang baik, karena lignin yang tinggi akan menggunakan bahan kimia tinggi juga sehingga tidak efisien dan memberikan sifat kaku pada produk pulp dan kertas. Dalam pemanfaatan selulosa dalam pembuatan pulp, kadar lignin juga sangat berpengaruh terhadap warna hasil pulp. Untuk itu kadar lignin harus dihilangkan agar sel-sel pada tanaman dapat terurai dengan baik. Begitu pula dengan industri tekstil, kadar lignin serat tinggi menghasilkan produk berkualitas rendah, berbanding terbalik jika kadar selulosa lebih tinggi dari pada kadar lignin akan menghasilkan produk berkualitas tinggi. Hal ini karena sifat kaku lignin sehingga tidak elastis dan kekuatan tarik berkurang. Selain pemakaian bahan kimia tinggi, kadar lignin=tinggi juga akan menghambat proses penggilingan sehingga produk berkualitas rendah.

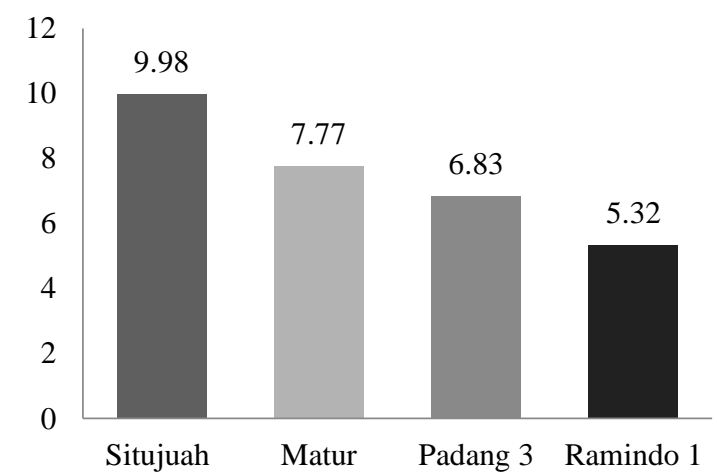

Gambar 6. Kadar lignin dari empat populasi tanaman rami

\section{KESIMPULAN}

Serat rami aksesi Situjuah berkadar air, abu, hemiselulosa, dan lignin tertinggi masing-masing 40,43; 6,74 ; 14,39; dan 9,98\%. Sedangkan serat rami aksesi Ramindo 1 mengandung holoselulosa dan selulosa tertinggi masing-masing 70,23 dan 58,46\%. Sehingga aksesi lokal yang sangat potensial dikembangkan dalam program pemuliaan tanaman adalah Matur.

\section{DAFTAR PUSTAKA}

Bahtiar ET, Nugroho N, Surjokusumo S, Karlinasari L, Nawawi DS, Lestari DP. 2016. Pengaruh Komponen Kimia dan Ikatan Pembuluh terhadap Kekuatan Tarik Bambu. Jurnal Teknik Sipil 23 (1) : 31-40.

Direktorat Jenderal Perkebunan. 2017. Statistik Perkebunan Indonesia Komoditas Kapas 2015-2017. Jakarta. Kementerian Pertanian.

Liu T, Tang S, Zhu S, Tang Q. 2014. QTL Mapping for Fiber Yield-Related Traits by Constructing the First Genetic Linkage Map in Ramie (Boehmeria nivea L. Gaud). Molecular Breeding 34 (3): 883-892.

Liu T, Zhu S, Tang Q, Tang S. 2015. Genome-Wide Transcriptomic Profiling of Ramie (Boehmeria nivea L. Gaud) in Response to Cadmium Stress. Gene 558: 131-137.

Lukmandaru G, Mohammad AR, Wargono P, Prasetyo VE. 2016. Studi Mutu Kayu Jati di Hutan Rakyat Gunung kidul. V. Sifat Kimia Kayu. Jurnal IImu Kehutanan 10 (2) : 108-118.

Maulana A. 2016. Analisis Parameter Mutu dan Kadar Flavonoid pada Produk Teh Hitam Celup. Unpublished Bachelor thesis, Fakultas Teknik Universitas Pasundan. Bandung.

Mayerni R. 2006. Prospek dan Peluang Tanaman Rami di Indonesia. Padang. Andalas University Press.

Mayerni R, Syarif A, Sartika R. 2018. Characterization of Agronomical and Quality from Three Clones of Ramie Plant (Boehmeria nivea (L.) Gaud.) in Ultisol Limau Manis. Jerami 1(1): 1-8.

Novika D. 2013. Degradasi Fraksi Serat (NDF, ADF, Selulosa dan Hemiselulosa) Ransum yang menggunakan Daun Cokelat secara In-vitro. Unpublished Bachelor thesis, Fakultas Peternakan Universitas Andalas. Padang.

Nurnasari E, Nurindah. 2017. Karakteristik Kimia Serat Buah, Serat Batang, dan Serat Daun. Buletin Tanaman Tembakau, Serat dan Minyak Industri 9 (2) : 64-72.

Pasaribu G, Sipayung B, Pari G. 2007. Analisis Komponen Kimia Empat Jenis Kayu Asal Sumatera Utara. Jurnal Penelitian Hasil Hutan 25 (4) :327-333.

Putera RDH. 2012. Ekstraksi Serat Selulosa dari Tanaman Eceng Gondok (Eichornia crassipes) dengan Variasi Pelarut. Unpublished Bachelor thesis, Fakultas Teknik Universitas Indonesia. Depok.

Putra AFR, Wardenaar E, Husni H. 2018. Analisa Komponen Kimia Kayu Sengon (Albizia falcataria (L.) Fosberg) berdasarkan Posisi Ketinggian Batang. Jurnal Hutan Lestari 6 (1) : 83-89.

Roza I. 2009. Pengaruh Perbedaan Proses Penyediaan Serat dengan Cara Mekanis Limbah Tandan Kosong Kelapa Sawit terhadap Papan Serat. Sainstek 12 (1) : 9-17. 
Sarkar D, Sinha MK, Kundu A, Kar CS, Saha A, Kharbikar LL, Mahapatra BS. 2010. Why is ramie the strongest yet stiffest bast fibre? Current Science 98: 1570-1572.

Satya P, Mitra S, Ray DP, Mahapatra BS, Karan M, Jana S, Sharma AK. 2013. Rapid and inexpensive $\mathrm{NaOH}$ based direct PCR for amplification of nuclear and organelle DNA from ramie (Boehmeria nivea), a bast fibre crop containing complex polysaccharides. Industrial Crops and Products 50: 532-536.

Subandi M. 2011. Budidaya Tanaman Perkebunan. Bandung. Gunung Djati Press.
Sunardi, Istikowati WT. 2012. Analisis Kandungan Kima dan Serat Tanaman Purun Tikus (Eleocharis dulcis) Asal Kalimantan Selatan. Bioscientiae 9 (2) : 15-25.

TAPPI. 2018. Technical Association for Pulp and Paper Industry. www.tappi.org (diakses 21 Maret 2018).

Trisiana LS, Maideliza T, Mayerni R. 2016. Kualitas Serat Lima Klon Tanaman Rami (Boehmeria nivea L. Gaud). Eksakta 1 (17) : 8-16.

Zhu S, Liu T, Tang Q, Tang S. 2012. Physio-ecological and Cytological Features of Ramie from Continuous Cropping System. Journal of Hunan Agricultural University (Natural Science) 38: 360-365. 